\title{
PENGARUH APLIKASI POC TERHADAP PERTUMBUHAN DAN PRODUKSI RUMPUT GAJAH PADA PEMOTONGAN KE DUA
}

\author{
Khalidin $^{1}$, Sri Rahayu ${ }^{2}$ \\ 1,2 Program Studi Peternakan Fakultas Pertanian \\ Universitas Jabal Ghafur Sigli
}

\begin{abstract}
Abstrak
Untuk mengetahui respon pertumbuhan dan produksi rumput gajah akibat aplikasi POC dilakukan suatu penelitian dengan menggunakan Metode Rancangan Acak Kelompok (RAK) yang terdiri dari empat perlakuan dengan enam ulangan. Masing-masing perlakuan adalah P0 (0 ml POC/ltr air sebagai kontrol), P1 (3 ml POC/ltr air), P2 (5 ml POC/ltr air) dan P3 (7 ml POC/ltr air). Parameter yang diamati yaitu tinggi tanaman, jumlah anakan, diameter batang dan produksi. Penggunaan POC dengan dosis yang berbeda berpengaruh sangat nyata terhadap tinggi rumput gajah, rumput gajah tertinggi dosis $7 \mathrm{ml} / \mathrm{lt}$. Jumlah anakan tidak dipengaruhi akibat dari aplikasi dosis POC. Lingkar batang akibat perlakuan dosis POC memperlihatkan adanya pengaruh yang nyata pada umur $20 \mathrm{HSPP}$ dan pada umur $35 \mathrm{HSPP}$ serta $50 \mathrm{HSPP}$ berpengaruh sangat nyata. Lingkar batang terbaik dijumpai pada perlakuan dosis POC $7 \mathrm{ml} / \mathrm{lt}$. Produksi rumput gajah pengaruh yang sangat nyata akibat dosis POC, produksi tertinggi dijumpai pada perlakuan dodis POC $7 \mathrm{ml} / \mathrm{lt}$.
\end{abstract}

Kata kunci: POC, rumput gajah, pertumbuhan dan produksi.

\section{Latar Belakang}

Hijauan merupakan sumber pakan utama untuk ternak ruminansia. Hal ini disebabkan hampir $90 \%$ pakan ternak ruminansia berasal dari hijauan dengan konsumsi segar perhari $10-15 \%$ dari berat badannya (Sirait et al., 2005). Untuk dapat memenuhi kebutuhan hijauan bagi ternak ruminsia, salah satu upaya yang dapat dilakukan adalah dengan mengembangkan jenis rumput yang mempunyai produktifitas tinggi serta berkualitas baik. Salah satu jenis rumput unggul yang mudah dikembangkan adalah rumput gajah. Adijaya et al., (2007) mengemukakan bahwa rumput gajah adalah hijauan makanan ternak tropik yang mudah dikembangkan, produksinya tinggi dan dapat dimanfaatkan sebagai makanan ternak ruminansia. Kemampuan produksi rumput gajah menurut Reksohadiprodjo (1994) adalah mencapai 270 ton/ha/ tahun. Rumput gajah dapat tumbuh pada daerah dengan ketinggian 0 - 3000 meter di atas permukaan laut (dpl.) dengan curah hujan $1000 \mathrm{~mm}$ tahun/tahun. Disamping produksinya yang tinggi rumput gajah mempunyai kandungan zat gizi yang cukup tinggi serta disukai oleh ternak ruminansia, dengan rata-rata kandungan zat-zat gizi yaitu: PK 9,66\%, BETN 41,34\%, SK 30,86\%, lemak 2,24\%, abu $15,96 \%$, dan total digestible nutrient (TDN) 51\% (Hartadi et al., 1986).

$$
\text { Rumput gajah sudah banyak }
$$
dikembangkan namun pada produksinya banyak yang masih belum maksimal. Belum maksimalnya produksi rumput tersebut salah satu penyebabnya adalah karena tingkat kesuburan tanah yang rendah karena rumput gajah banyak dikembangkan pada lahanlahan marjinal. Upaya yang dapat dilakukan guna meningkatkan produksi rumput gajah yang ditanam pada lahan-lahan marginal adalah melalui pemupukan. Salah satu alternatif pemupukan yang dapat dilakukan adalah dengan menggunakan pupuk orgabik cair (POC).

Adijaya et al (2007) melaporkan bahwa pemberian 1,7 liter/ha pupuk cair untuk rumput raja pada lahan kering masam mampu memberikan pertumbuhan dan produksi rumput raja tertinggi dibandingkan dengan tanpa pemupukan. Tarigan (1988) 
mengemukakan bahwa POC merupakan pupuk yang dapat memberikan unsur hara yang sesuai dengan kebutuhan tanaman, karena bentuknya yang cair akan mudah mengatur penyerapan komposisi pupuk yang dibutuhkan.

Untuk mengetahui seberapa besar pengaruh dari pupuk organik cair pada rumput gajah maka dilakukan penelitian guna mengetahui berapa dosis aplikasi POC yang baik terhadap pertumbuhan dan produksi rumput gajah pada pemotongan ke dua.

\section{Rumusan Masalah}

Apakah terdapat pengaruh dari dosis POC terhadap pertumbuhan dan produksi rumput gajah pada pemotongan ke dua.

\section{Tujuan Penelitian}

Untuk mengetahui dosis POC terbaik untuk pertumbuhan dan produksi rumput gajah pada pemotongan ke dua.

\section{Hipotesis}

Dosis POC berpengaruh terhadap Pertumbuhan dan produksi rumput gajah pada pemotongan ke dua.

\section{METODE PENELITIAN}

\section{Waktu dan Tempat Penelitian}

Penelitian akan dilaksanakan di kebun penelitian Prodi Peternakan Fakultas Pertanian Universitas Jabal Ghafur yang dimulai pada tanggal 1 April 2017 sampai dengan 21 Mei 2017.

\section{Materi dan Alat Penelitian}

Materi yang digunakan dalam penelitian ini terdiri dari stek rumput gajah yang diambil dari kebun Prodi Peternakan Fakultas Pertanian Universitas Jabal Ghafur. Pupuk Urea, KCl dan SP 36. Pupuk Organik Cair hasil fermentasi berbahan dasar kotoran sapi.

Alat-alat Alat-alat yang digunakan antara lain: cangkul, skop, garu, parang, sabit, timbangan, meteran untuk mengukur lingkar batang.

\section{Prosedur Penelitian}

1. Plot penelitian berukuran $2 \times 2$ meter yang sebelumnya telah dilakukan pemotongan pertama pada 50 HST

2. Plot-plot penelitian dibersihkan dari gulma dengan cara dicangkul dan dirapikan kembali.

3. Rumput gajah sebagai tanaman pengamatan adalah berasal dari penanaman sebelumnya yang ditanam menggunakan stek yang masing-masing panjangnya 3 ruas dengan cara membenamkan sedalam 1 ruas sebanyak 1 stek di setiap lubangnya dengan jarak tanam $50 \mathrm{~cm} \times 50 \mathrm{~cm}$.

4. Pupuk anorganik sebagai pupuk dasar diberikan dengan cara ditabur merata pada semua plot penelitian kemudian digaru agar bercampur merata dengan tanah dengan dosis Urea 40 gr/plot (setara $100 \mathrm{~kg} / \mathrm{ha}$ ), SP36 $20 \mathrm{gr} / \mathrm{plot}$ (setara $50 \mathrm{~kg} / \mathrm{ha}$ ), dan $\mathrm{KCl} 20 \mathrm{gr} / \mathrm{plot}$ (setara dengan $50 \mathrm{~kg} / \mathrm{ha}$ ).

5. Penyiraman dilakukan setelah pemberian pupuk sampai mencapai kapasitas lapang, selanjutnya penyiraman dilakukan sesuai kondisi kelembaban tanah.

6. Penyiangan dilakukan secara manual dengan cara mencabut setiap gulma yang terdapat pada setiap plot.

7. Pemberian POC dilakukan dengan cara menyiram dengan memakai gembor kapasitas 15 liter air/plot.

\section{Rancangan Penelitian}

Penelitian dilakukan dengan menggunakan Rancangan Acak Kelompok (RAK) yang terdiri dari 4 perlakuan dengan 6 ulangan. Data yang diperoleh dianalisis sidik ragam dengan model matematik sbb:

$$
\begin{aligned}
\text { Yijk }= & \mathrm{m}+\mathrm{bi}+\mathrm{t} \mathrm{j}+\text { eijk } \\
\text { Keterangan: } & \\
\mathrm{Y}_{\mathrm{ijk}}= & \text { Nilai pengamatan pada ulangan ke- } \\
& \mathrm{i} \text { dan perlakuan ke- } \mathrm{j} \\
\mu \quad= & \text { Rata-rata umum } \\
\beta \mathrm{i}= & \text { pengaruh ulangan ke- } \mathrm{i} \\
\tau \mathrm{j}= & \text { Pengaruh perlakuan ke- } \mathrm{j} \\
\varepsilon \mathrm{ij} \quad= & \text { Kesalahan (galat) percobaan pada } \\
& \text { ulangan ke-i dan perlakuan ke- } \mathrm{j}
\end{aligned}
$$


Jika terdapat pengaruh nyata atau sangat nyata maka dilanjutkan dengan uji BNT. adalah:

Adapun perlakuan dari penelitian ini

$1 \mathrm{P}_{0}=$ Tanpa POC

$2 \mathrm{P}_{1}=3 \mathrm{ml} \mathrm{POC} / \mathrm{ltr}$ air

$3 \mathrm{P}_{2}=5 \mathrm{ml} \mathrm{POC} / \mathrm{ltr}$ air

$4 \mathrm{P}_{3}=7 \mathrm{ml} \mathrm{POC} / \mathrm{ltr}$ air

\section{Pengamatan}

Variable yang diamati yaitu: tinggi tanaman, jumlah anakan, lingkar batang dan produksi masing-masing pada umur 20 hari setelah pemotongan pertama (HSPP), 35 HSPP dan 50 HSPP.

\section{HASIL DAN PEMBAHASAN Tinggi Tanaman}

Tinggi rumput gajah hasil penelitian yang dianalisis dengan menggunakan sidik ragam memperlihatkan penggunaan POC dengan dosis yang berbeda berpengaruh sangat nyata terhadap tinggi rumput gajah. Rata-rata tingginya dapat dilihat pada Gambar 1 dibawah.

Gambar 2. Tinggi Rumput Gajah (cm)

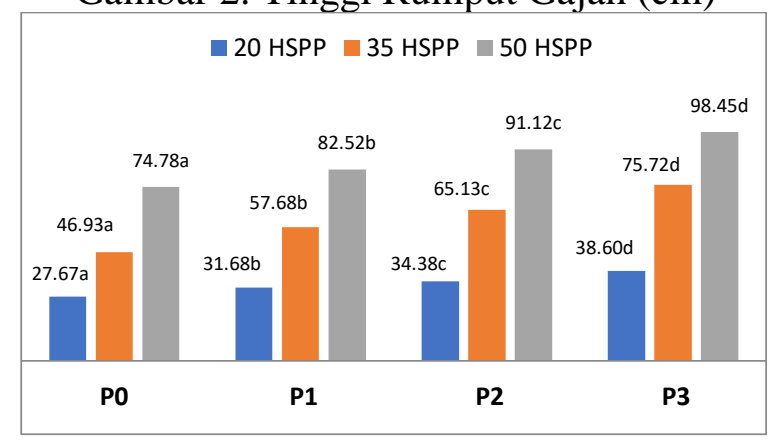

Keterangan: Angka yang diikuti oleh huruf yang sama tidak berbeda nyata, huruf berbeda menunjukkan perbedaan yang sangat nyata (Uji BNJ)

Pertumbuhan rumput gajah mulai dari periode awal pengamatan yaitu 20 HSPP sampai dengan umur 50 HSPP terlihat tingginya sangat berbeda nyata, dimana semakin tinggi dodis POC yang diberikan maka semakin tinggi rumput gajahnya.
Rumput gajah yang tertinggi pada periode 20 HSPP terdapat pada perlaukuan POC $7 \mathrm{ml} / \mathrm{lt}$ $(38,6 \mathrm{~cm})$, kemudian berturut-turut dosis 5 $\mathrm{ml} / \mathrm{lt}(34,38 \mathrm{~cm}), 3 \mathrm{ml} / \mathrm{lt}(31,68 \mathrm{~cm})$ dan yang terendah $0 \mathrm{ml} / \mathrm{lt}(27,67 \mathrm{~cm})$.

Pada umur 35 HSPP rumput gajah tertinggi dijumpai pada perlakuan POC 7 $\mathrm{ml} / \mathrm{lt}(75,72 \mathrm{~cm})$, kemudian berturut-turut dosis $5 \mathrm{ml} / \mathrm{lt}(65,13), 3 \mathrm{ml} / \mathrm{lt}(57,68 \mathrm{~cm})$ dan yang terendah $0 \mathrm{ml} / \mathrm{lt}(46,93 \mathrm{~cm})$. Demikian juga pada umur 50 HSPP POC 7 ml/lt $(98,45$ $\mathrm{cm})$, kemudian berturut-turut dosis $5 \mathrm{ml} / \mathrm{lt}$ $(91,12), 3 \mathrm{ml} / \mathrm{lt}(82,52 \mathrm{~cm})$ dan yang terendah $0 \mathrm{ml} / \mathrm{lt}(74,78 \mathrm{~cm})$.

Walaupun secara keseluruhan tinggi rumput gajah dipengaruhi sangat nyata akibat pemberian POC dengan dosis yang berbeda, namun tingginya lebih rendah dibandingkan dengan pada pemotongan pertama. Hasil penelitian sebelumnya Khalidin (2018), tinggi rumput gajah dengan perlakuan yang sama adalah sebagai berikut:

Table 1. Tinggi Rumput Gajah pada Pemotongan Pertama

\begin{tabular}{|c|c|c|c|c|}
\hline \multirow{2}{*}{$\begin{array}{c}\text { Umur } \\
\text { HST }\end{array}$} & \multicolumn{4}{|c|}{ Dosis POC } \\
\cline { 2 - 5 } & $0 \mathrm{ml} / \mathrm{lt}$ & $3 \mathrm{ml} / \mathrm{lt}$ & $5 \mathrm{ml} / \mathrm{lt}$ & $7 \mathrm{ml} / \mathrm{lt}$ \\
\hline 20 & $26,08 \mathrm{a}$ & $27,68 \mathrm{~b}$ & $27,32 \mathrm{ab}$ & $28,82 \mathrm{~b}$ \\
\hline 35 & $66,38 \mathrm{a}$ & $67,44 \mathrm{ab}$ & $72,56 \mathrm{~b}$ & $75,39 \mathrm{c}$ \\
\hline 50 & $91.9 \mathrm{a}$ & $96,87 \mathrm{a}$ & $100,15 \mathrm{a}$ & $117,77 \mathrm{~b}$ \\
\hline
\end{tabular}

Pertumbuhan periode awal pada pemotongan ke dua, rumput gajah terlihat lebih tinggi dari pada periode awal pemotongan pertama. Hal ini desebabkan pada periode pertama yang ditanam adalah berupa stek, sehingga tanaman membutuhkan waktu dalam masa pertumbuhan awalnya yaitu pembentukan akar dan penyebarannya. Sedangkan pada periode ke dua akar telah terbentuk dan menyebar dengan sempurna sehingga dapat langsung menyarap unsur-unsur hara yang tersedia.

Pada periode selanjutnya tinggi rumput gajah terlihat lebih rendah dibandingkan dengan pada periode yang sama pada pemotongan pertama. Hal ini desebabkan karena rendahnya curah hujan dibandingkan 
waktu penanaman pada pemotongan pertama. Akibat curah hujan rendah dan tingginya suhu maka tanaman kekurangan air sehingga pertumbuhan rumput gajah tidak dapat berlangsung secara maksimal. Djaenudin et all., (2003) menjelaskan bahwa unsur iklim yang penting bagi pertumbuhan tanaman adalah curah hujan, suhu, kelembaban udara.

Menurut Hanafiah (2005) beberapa peranan yang menguntungkan dari air dalam tanah adalah: 1. Sebagai pelarut dan pembawa ion-ion hara dari rhizosfer ke dalam akar tanaman. 2. Sebagai pelarut dan pemicu reaksi kimia dalam penyediaan hara, yaitu dari hara tidak tersedia menjadi hara yang tersedia bagi akar tanaman. 3. Sebagai penopang aktivitas mikrobia dalam merombak unsur hara yang semula tidak tersedia menjadi tersedia bagi akar tanaman.

Hidayati et all., (2017) mengemukakan bahwa tanaman nyamplung dengan perlakuan kekeringan pada hari ke-40 dan disimpulkan bahwa cekaman kekeringan menyebabkan terhambatnya pertumbuhan tinggi tanaman.

\section{Jumlah Anakan}

Hasil analisis sidik ragam dari data jumlah anakan menunjukkan bahwa rata-rata jumlah anakan tidak berpengaruh nyata akibat dari aplikasi dosis POC. Hasilnya ditampilkan pada Gambar 2 berikut.

Gambar 2. Jumlah Anakan

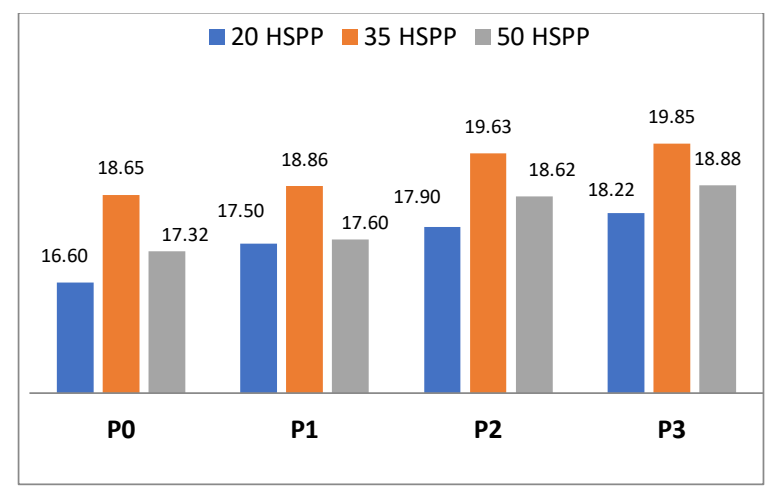

Pada Gambar 2 di atas menunjukkan bahwa walaupun jumlah anakan tidak berbeda nyata akibat perlakuan dosis POC namun terlihat semakin tinggi dosis POC yang diaplikasikan jumlah anakannya semakin banyak. Jumlah anakan pada periode pemotongan ke dua lebih banyak dibandingkan dengan periode pertama. Pada periode pertama jumlah anakannya adalah berkisar 3,18 sampai yang terbanyak 10,1 batang (Khalidin, 2018). Sedangkan pada periode ke dua anakan berkisar 16,6 sampai dengan 19,85 batang. Banyaknya jumlah anakan pada periode ke dua karena pertumbuhan rumput gajah telah berlangsung dengan sempurna. Unsur-unsur hara yang diserap tanaman digunakan dengan maksimal untuk pembentukan anakan. Berbeda dengan jumlah anakan pada pemotongan pertama bahwa ketersediaan unsur hara akan dimanfaatkan oleh tanaman rumput gajah lebih dominan untuk pertumbuhan tingginya dan memperbesar lingkar batang bukan untuk memperbanyak jumlah anakan (Khalidin, 2018).

\section{Lingkar Batang}

Hasil analisis sidik ragam terhadap rata-rata lingkar batang rumput gajah memperlihatkan adanya pengaruh yang nyata pada umur 20 HSPP dan pada umur 35 HSPP serta 50 HSPP berpengaruh sangat nyata. Akibat dari aplikasi dosis POC. Rata-rata lingkar batang hasil penelitian dapat dilihat pada Gambar 3 di bawah.

Gambar 3. Lingkar Batang (cm)

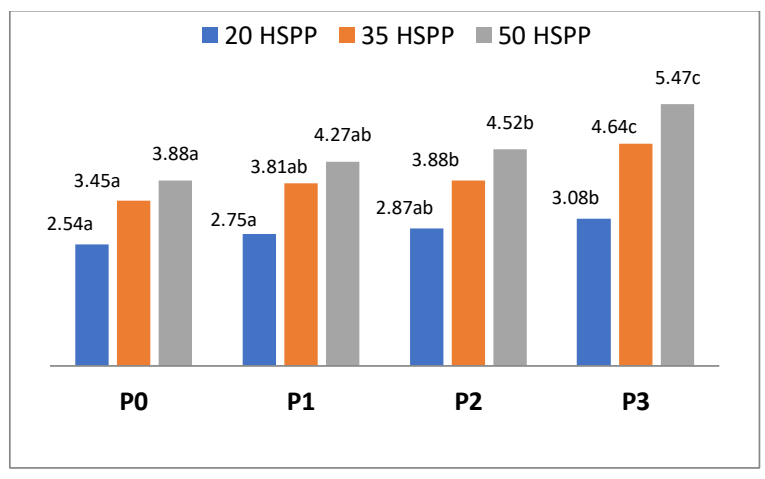

Keterangan: Angka yang diikuti oleh huruf yang sama tidak berbeda nyata, huruf berbeda menunjukkan perbedaan yang sangat nyata (Uji BNJ) 
Lingkar batang pada Gambar 3 di atas memperlihatkan bahwa semakin tinggi dosis POC yang diberikan lingkar batangnya semakin besar. Lingkar batang yang terbesar pada umur 50 HSPP terdapat pada perlakuan $7 \mathrm{ml} / \mathrm{lt}$ POC $(5,47 \mathrm{~cm})$ berbeda sangat nyata dengan perlakuan lainnya. Pada umur 35 dan 20 HSPP, masing-masing lingkar batang adalah 4,64 dan 3,08 cm, berbedan sangat nyata pada umur 35 HSPP dan berbeda nyata pada umur 20 HSPP.

Lingkar batang pada pemotongan ke dua lebih kecil dari pada pemotongan pertama, hal ini dikarenakan saat masa pertumbuhan pada pemotongan ke dua kondisi curah hujan rendah sehingga rumput gajah kurang terpenuhi air sehingga pertumbuhannnya tidak dapat berlangsung secara maksimal.

Table 2. Lingkar Batang Rumput Gajah pada Pemotongan Pertama

\begin{tabular}{|c|c|c|c|c|}
\hline \multirow{2}{*}{$\begin{array}{c}\text { Umur } \\
\text { HST }\end{array}$} & $0 \mathrm{ml} / \mathrm{lt}$ & $3 \mathrm{ml} / \mathrm{lt}$ & $5 \mathrm{ml} / \mathrm{lt}$ & $\begin{array}{c}7 \\
\mathrm{ml} / \mathrm{lt}\end{array}$ \\
\cline { 2 - 5 } & 2,7 & 2,87 & 3 & 3,2 \\
\hline 20 & $3,75 \mathrm{a}$ & $4,1 \mathrm{ab}$ & $4,23 \mathrm{~b}$ & $4,93 \mathrm{c}$ \\
\hline 55 & $4,18 \mathrm{a}$ & $4,75 \mathrm{ab}$ & $5,05 \mathrm{~b}$ & $6 \mathrm{c}$ \\
\hline 50
\end{tabular}

Sumber: Khalidin (2018)

Hidayati et all., (2017) mengemukakan bahwa perlakuan kekeringan pada hari ke-40 bahwa cekaman kekeringan menyebabkan terhambatnya diameter batang tanaman nyamplung. Akram et all., (2013) menjelaskan bahwa kekeringan dapat menyebabkan laju fotosintesis tanaman menurun secara signifikan pada semua tahap pertumbuhan.

\section{Produksi}

Rata-rata produksi rumput gajah dari hasil penelitian yang dianalisis dengan menggunakan sidik ragam memperlihatkan bahwa terdapat pengaruh yang sangat nyata akibat dosis POC. Produksi rumput gajah dapat dilihat pada Gambar 4 di bawah.
Gambar 4. Produksi Rumput Gajah (Ton/Ha)

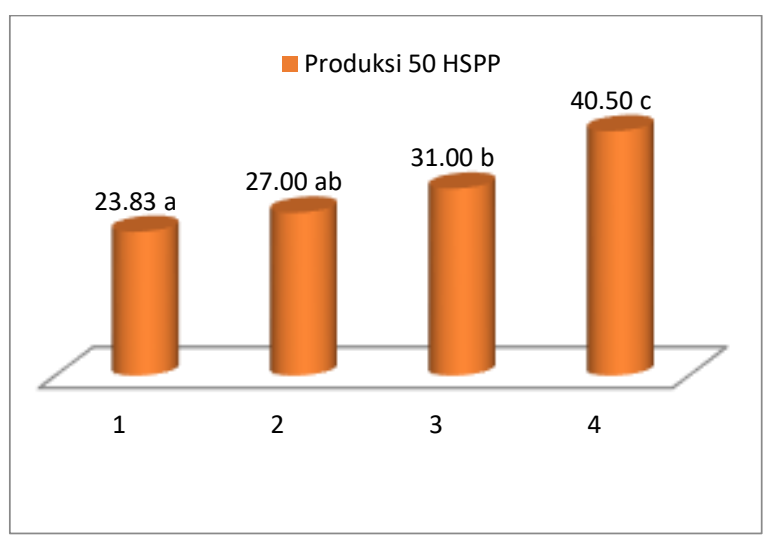

Keterangan: Angka yang diikuti oleh huruf yang sama tidak berbeda nyata, huruf berbeda menunjukkan perbedaan yang sangat nyata (Uji BNJ)

Produksi rumput gajah tertinggi pada pemotongan ke dua secara berurut terdapat pada perlakuan dosis POC $7 \mathrm{ml} / \mathrm{lt}$ yaitu 40,50 ton/ha, $5 \mathrm{ml} / \mathrm{lt}$ (31,00 ton/ha), $3 \mathrm{ml} / \mathrm{lt}(27,00$ ton/ha) dan $0 \mathrm{ml} / \mathrm{lt} \quad(23,83$ ton/ha). Dibandingkan dengan pemotongan pertama produksi rumput gajah lebih rendah dari pada pemotongan ke dua. Datanya dapat dilihat pada Gambar 5 di bawah. Selisih produksi rumput gajah dari masing-masing perlakuan adalah: POC $7 \mathrm{ml} / \mathrm{lt}$ ( 8 ton/ha), $5 \mathrm{ml} / \mathrm{lt}(4,5$ ton/ha), $3 \mathrm{ml} / \mathrm{lt}$ (3,83 ton/ha) dan $0 \mathrm{ml} / \mathrm{lt}$ (1,5 ton/ha). Pertumbuhan tanaman terjadi karena pembelahan, pembesaran, dan diferensiasi sel yang melibatkan unsur genetik, fisiologi, ekologi, dan morfologi serta interaksinya. Kualitas dan kuantitas pertumbuhan tanaman bergantung pada unsur tersebut, yang dipengaruhi oleh ketersediaan air (Farooq et al., 2009). Fischer and Fukai (2003) mengemukakan bahwa kekurangan air mengakibatkan proses fisiologis maupun morfologis tidaknormal, yang menyebabkan pertumbuhan tanamanter hambat atau terhenti

Gambar 5. Perbandingan Produksi Rumput

Gajah (Ton/Ha) 


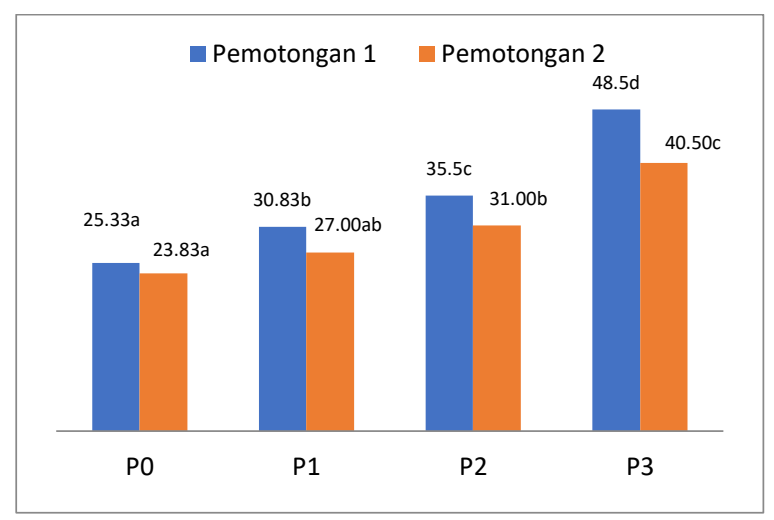

\section{Kesimpulan}

1. Penggunaan POC dengan dosis yang berbeda berpengaruh sangat nyata terhadap tinggi rumput gajah, rumput gajah tertinggi terdapat pada perlakuan POC dosis $7 \mathrm{ml} / \mathrm{lt}$

2. Jumlah anakan tidak dipengaruhi akibat dari aplikasi dosis POC.

3. Lingkar batang akibat perlakuan dosis POC memperlihatkan adanya pengaruh yang nyata pada umur 20 HSPP dan pada umur 35 HSPP serta 50 HSPP berpengaruh sangat nyata. Lingkar batang terbaik dijumpai pada perlakuan dosis POC $7 \mathrm{ml} / \mathrm{lt}$.

4. Produksi rumput gajah pengaruh yang sangat nyata akibat dosis POC, produksi tertinggi dijumpai pada perlakuan dodis POC $7 \mathrm{ml} / \mathrm{lt}$.

\section{Saran}

1. Perlu dilakukan penelitian yang sama untuk melihat pengaruhnya pada pemotongan ke tiga.

2. Perlu dilakukan penelitian lainnya untuk mengetahui dosis POC maksimal pada rumput gajah.

\section{DAFTAR PUSTAKA}

Adijaya, N., I.M. Rai Yasa dan S. Guntoro. 2007. Pemanfaatan Bio Urine dalam Produksi Hijauan Pakan Ternak Rumput Gajah. Prosiding Seminar Nasional Percepatan Transformasi Teknologi Pertanian untuk Mendukung Pembangunan Wilayah. Balai Besar Pengkajian dan Pengembangan Teknologi Pertanian Bekerjasama dengan Balai Pengkajian Teknologi Pertanian Bali.

Akram, H. M., A. Ali, A. Sattar, H.S.U. Rehman, and A. Bibi. 2013. Impact of Water Deficit Stress on Variousphysiological and Agronomic Traits of Three Basmatirice Ioryza sativa L. ) Cultivar. The Journal Animal and Sciences 23(5):1415-1423.

Djaenudin, D., Marwan, H., Subagjo, H., dan A. Hidayat. 2011. Petunjuk Teknis Evaluasi Lahan Untuk Komoditas Pertanian. Balai Besar Litbang Sumberdaya Lahan Pertanian. Badan Litbang Pertanian. Bogor. 36p.

Farooq, M., A. Wahid, N. Kobayashi, D. Fujita, and S. M. A. Basra. 2009. Plant Drought Stress: Effect, Mechanismand Management. Agron. Sustain. Dev. 29:185-212.

Fischer, K.S. dan Fukai, S. 2003. How rice responds to drought. Cit. Fischer, K.S., Lattife, R., Fukai, S., Atlin, G., and Hardy, B. Breeding Rice for Drought Prone Enviroments. International Rice Research Institute, Los Banõs, Philippines.

Hanafiah. 2005. Biologi Tanah, Ekologi dan Morfologi Tanah. Raja grafindo Persada. Jakarta.

Hartadi, H., S. Reksohadiprodjo dan A.D. Tillman. 1986. Tabel Komposisi Pakan untuk Indonesia. Gadjah Mada University Press. Yogyakarta.

Hidayati, N., R. L. Hendrati., A. Triani, dan Sudjino. 2017. Pengaruh Kekeringan terhadap Pertumbuhan dan Perkembangan Tanaman Nyamplung (Callophylum inophyllum L.) dan Johar (Cassia florida Vahl.) dari Provenan yang Berbeda. 
Khalidin. 2017. Pengaruh Aplikasi POC terhadap Pertumbuhan dan Produksi Rumput Gajah pada Pemotongan Pertama. Jurnal Agro Ristek Volume I - Nomor 1, April 2018.

Reksohadiprodjo (1994). Produksi Hijauan Makanan Ternak Tropik. BPFE Universitas Gajah Mada . Yogyakarta.

Sirait, J., N. D. Purwantari dan K. Simanihuruk. 2005. Produksi dan Serapan Nitrogen Rumput pada Naungan dan Pemupukan yang Berbeda. Jurnal Ilmu Ternak dan Veteriner, 10 (3) : 175 - 181. 